\title{
The Factors of Needlestick Injury on Healthcare Workers at the Hospital of Bojonegoro
}

\author{
Faktor Kecelakaan Tertusuk Jarum pada Petugas Kesehatan di Rumah Sakit \\ Bojonegoro
}

\author{
Anisa Fitria ${ }^{1}$, Deviyanti Wahyu Izati ${ }^{2}$, Tri Martiana ${ }^{3}$ \\ ${ }^{1,3}$ Department of Occupational Safety and Healthe, Faculty of Public Health, Universitas Airlangga \\ Campus C Mulyorejo, Surabaya, East Java, 60115 Indonesia \\ ${ }^{2}$ RSUD Dr. R. Sosodoro Djatikoesoemo Bojonegoro \\ Jl. Veteran No.36, Bojonegeoro District, Bojonegoro, East Java, 62111 Indonesia
}

\begin{abstract}
Introduction: Needlestick injury is the most frequent accidents encountered by healthcare workers in the hospital. Needlestick injury can expose healthcare workers to the risk of communicable diseases infection. This study was conducted in one of the hospitals in Bojonegoro. Healthcare workers in the inpatient installation and laboratory room have a potential for needlestick injury since they often use needles in their work activities. The aim of this study was to analyze the needlestick injury-related factors on healthcare workers in one of the hospitals in Bojonegoro. Methods: This study belongs to a cross-sectional study with a quantitative approach. The study population comprised all laboratory staffs and nurses in the inpatient installation. Sampling was done using stratified random method, obtaining 91 people as the samples. The variables involved in this study included educational level, knowledge, training, unsafe action, and needlestick injury. Data were acquired by means of observation, questionnaire, hospital data, and other supporting data. The data obtained were analyzed using the chi square test with a significance of $0.05(\alpha=0.05)$. Result: This study indicates that educational level $(\mathrm{sig}=0.024)$ and unsafe action $(\mathrm{sig}=0.002)$ are related to needlestick injury. Meanwhile, knowledge $(\operatorname{sig}=0.722)$ and training $(\operatorname{sig}=0.350)$ are not related to needle stick injury. Conclusion: Educational level and unsafe actions are related to needlestick injury on healthcare workers at one of the hospitals in Bojonegoro.
\end{abstract}

Keywords: accident, hospital, needlestick

\begin{abstract}
ABSTRAK
Pendahuluan: Kecelakaan tertusuk jarum merupakan suatu kecelakaan yang paling sering dialami oleh tenaga kesehatan di rumah sakit. Kecelakaan tertusuk jarum dapat menyebabkan tenaga kesehatan berisiko terinfeksi penyakit menular. Penelitian ini dilakukan di salah satu rumah sakit di Bojonegoro. Tenaga kesehatan di instalasi rawat inap dan ruang laboratorium memiliki potensi untuk mengalami kecelakaan tertusuk jarum karena sering menggunakan jarum dalam aktivitas pekerjaanya. Penelitian ini bertujuan untuk menganalisis faktor yang dapat berhubungan dengan kecelakaan tertusuk jarum pada petugas kesehatan di salah satu rumah sakit di Bojonegoro. Metode: Penelitian ini tergolong dalam penelitian cross-sectional dengan pendekatan kuantitatif. Populasi penelitian meliputi seluruh petugas laboratorium dan perawat di instalasi rawat inap. Pengambilan sampel dilakukan dengan metode stratified random sampling yang menghasilkan sampel sebanyak 91 orang. Variabel dalam penelitian ini meliputi tingkat pendidikan, pengetahuan, pelatihan, tindakan tidak aman, dan kecelakaan tertusuk jarum. Data diperoleh melalui observasi, kuesioner, data rumah sakit, dan data penunjang lainnya. Data yang telah diperoleh dianalisis menggunakan uji chi-square dengan signifikansi sebesar 0.05 ( $\alpha=0.05)$. Hasil: Penelitian ini menunjukkan tingkat pendidikan (sig=0.024) dan tindakan tidak aman (sig=0.002) berhubungan dengan kecelakaan tertusuk jarum. Sedangkan, pengetahuan (sig=0.722) dan pelatihan (sig=0.350) tidak berhubungan dengan kecelakaan tertusuk jarum. Simpulan: Tingkat pendidikan dan tindakan tidak aman berhubungan dengan kecelakaan tertusuk jarum pada petugas kesehatan di salah satu Rumah Sakit di Bojonegoro.
\end{abstract}

Kata kunci: jarum, kecelakaan, rumah sakit

Corresponding Author:

Anisa Fitria

Email: anisaftr26@gmail.com

Telephone: +6281333511239

\section{INTRODUCTION}

Every workplace definitely holds potential hazards. The potential hazards of each workplace 
may vary depending on the work's characteristics or the workplace situation. According to Ramli (2010), hazard can be defined as an action or situation that has the potential to cause disruption to the humans, accidents or injuries, as well as causing damage or disruption to other aspects.

Potential hazards of occupational safety and health does not limit itself to good-producing industries like manufacturing. Potential hazards of occupational safety and health can also be found in ministrations industries or institutions. One of the ministrations institutions with various potential hazards of occupational safety and health is hospital (OSHA, 2013).

Referring to Minister of Health Regulation Number 66 of 2016, hospital is among the health institutions that provide complete individual health services. Hospital is also the institution with high and complex risks of safety and health. These safety and health risks are not only exposed to patients, but also to healthcare workers, hospital staff, visitors, and the environment.

Healthcare workers are the human resource that holds a critical role in the hospital's operational activities. When doing their work, they are confronted with an array of potential hazards. One of the types of potential hazards in the hospital is mechanical hazard. The mechanical hazard that often exposed to healthcare workers is punctured by needles. When a healthcare worker is punctured by needles, a healthcare worker can also be exposed to the biological hazard (microorganism). Such hazards cannot be simply left behind since healthcare workers will have risks of injuries and/or infection of certain diseases (World Health Organization and International Labour Organization, 2018).

Occupational accident is an event caused by the work and can cause injury in human (International Labour Organization, 2015). The occupational accident can also be defined as an undesirable event that can cause loss to human, damage to property, and loss in the work process (Budiono, Jusuf and Pusparini, 2016).

There are various factors causing occupational accidents. Educational level and skill can contribute to the occupational accident. Less optimum training and supervision, as well as exhaustion and work-related stress, can also be the causes of the occupational accident. Additionally, unsafe action and unsafe condition constitute the direct factors of occupational accident (Tarwaka, 2017).

In a study conducted by Laranova, Afriandi and Pratiwi (2018), it has come to light that the most prevalent occupational accident in hospital is needlestick injury. Another study also revealed that needlestick injury is the second most prevalent occupational accident after sharp object cut injury (Mawarni and Taiyep, 2019).

Pursuant to Minister of Health Regulation Number 52 of 2018, needlestick injury is categorized to high-risk hazard. A study by Ramdan and Rahman (2018) supports this as they stated that the highest risks of occupational safety and health is needlestick injury.

Referring to Minister of Health Regulation Number 27 of 2017, needlestick injury is one of the occupational accidents that cause wound and potential infection. This is in line with the World Health Organization and International Labour Organization (2018) statement that needlestick injury can lead to more risks of Hepatitis type B, Hepatitis type $\mathrm{C}$, and HIV infection.

Needlestick injury can occur due to the use of various types of needles. Bouya et al. (2020) in their study results disclosed that syringe needle is the device that most often causes needlestick injury. Furthermore, suture needle, intravenous (IV) cannula and lancet are also the types of needles that cause needlestick injury.

Yazie, Chufa and Tebeje (2019) in their study revealed that needlestick injury can be caused by several factors such as long working hours, availability and use of PPE, inadequate training, and excessive workload. Another essential factor which also relates to the occurrence of needlestick injury is healthcare workers' awareness.

Soleman and Nugroho (2017) in their research showed that the majority of healthcare workers experience wound from sharp objects, while opening vial for injection, recapping needle, and injecting. Another study result suggested that healthcare workers have needlestick injury while installing infusion and withdrawing blood (Laranova, Afriandi and Pratiwi, 2018). On the other hand, study conducted by Çiçek-Şentürk et al., (2019) showed different results that workers often experience needlestick injury during invasive procedure, disposing used needles, and drawing blood.

A study conducted by Sriram (2019) obtained results that the majority of needlestick injuries occur in the inpatient area. Sastry, Rajshekhar and Bhat, (2017), in their study results, revealed that many needlestick injuries occur in the inpatient area, operation room, and ICU. Whereas, the results of another study showed that the emergency room and 
ICU are places with the most needlestick injuries, followed by the inpatient room (Goel et al., 2017).

Garus-Pakowska and Górajski (2019) stated that nurses are the human resource with most cases of needlestick injury. Other healthcare workers who share the same risk are laboratory staff. A study by Mekonnen et al. (2018) showed that needlestick and sharp object injuries are more likely to occur to nurses, laboratory staff, and midwives. Another study also suggested that most laboratory staff encountered needlestick injury (Al-Abhar et al., 2020).

This research was executed in one of the hospitals in Bojonegoro. Similar to the other hospitals, this one has facilities of inpatient, outpatient (polyclinic), emergency installation, and supporting facilities such as a laboratory. Such facilities aim to provide optimum healthcare.

An assortment of medical equipment is used by healthcare workers in providing health services. High work demand must also be fulfilled by the healthcare workers. Such conditions might lead to potential safety and health-related issues on them (Braeseke et al., 2011).

To find an overview of occupational safety and health issues occurring in the hospital of the study's location, an interview was held with the worker who was responsible for accident reporting in this hospital. The results of preliminary interview indicated that needlestick injury is an occupational accident that often occurs in this hospital.

The interview revealed that the inpatient installation and laboratory room are the places where potential needlestick injury exists. This is due to the involvement of needlestick in the work activities in the place. Those work activities include infusion, injection, and blood sample collection.

Pursuant to Minister of Health Regulation Number 66 of 2016, the hospital management is responsible for all potential hazards and risks in the hospital by implementing occupational safety and health measures. Such measures have to be done consistently to ensure continuous improvement. In addition, occupational safety and health measures can also lower the risks of occupational accident and occupational disease in the hospital.

Considering the description that has been explained above, it is necessary to conduct identification and analysis to learn what factors causing needlestick injury cases on healthcare workers, which in this study refer to nurses and laboratory staff. The identification and analysis of related factors can help in determining control measures to increase occupational safety, hence needlestick injury risks in healthcare workers can be reduced.

Therefore, as stated in the background, the aim of this study was to analyze the needlestick injuryrelated factors on healthcare workers at one of the hospitals in Bojonegoro.

\section{METHODS}

This study is observational study considering the absence of intervention to the study's subject or variables. According to the analysis, this study belongs to an analytical study with a quantitative approach. Whereas, according to the time of study, since the study was done in a specific time, which was in March 2019, then this study was included in the cross-sectional study.

This study took place in one of the hospitals in Bojonegoro District, East Java. The population included all nurses in the inpatient installation and all laboratory staffs. There were 124 nurses and 16 laboratory staffs. Thus, the total population in this study was 140 people.

The determination of the sample number was based on probability sampling. The technique used to collect samples was stratified random sampling technique. After proportion calculation was done, a total of 91 respondents consisting of 81 nurses and 10 laboratory staff were gathered as samples.

Independent variables in this study included educational level, knowledge, training, and unsafe action. Meanwhile, the dependent variable of the study was needlestick injury.

Data collected in this study included primary and secondary data. Primary data were collected from questionnaire and observation on the respondents. The questionnaire were used to obtain data on educational level, knowledge, training, and needlestick injury. The observation was executed to obtain data on unsafe action with the guidance of an observation sheet. Meanwhile, secondary data were collected from hospital dossier that contains reports of the accident, the number of workers, and the standard operating procedures. Additionally, to support the study, other relevant secondary data were collected from journals, regulations, and books.

Related to the data analysis method, this study was an analytical with the type of data processed were quantitative data. Obtained data were then analyzed univariately using statistical and bivariately using a chi-square test. Univariate analysis was done to describe the educational level, knowledge, training, and unsafe actions as independent variables 
and needlestick injury as dependent variables, which were presented in a frequency distribution table. Meanwhile, bivariate analysis was done to learn the relationship between the independent and dependent variables. Bivariate analysis was presented in crosstabulation. In order to learn the relationship between independent and dependent variables, an analysis was done using chi-square test with $95 \%$ confidence level or significance value of $0.05(\alpha=0.05)$.

This study has acquired ethical certificate before its commencement. The ethical certificate was obtained from ethical committee of the Public Health Faculty of Universitas Airlangga. The ethical number that appears on the ethical certificate is 79/ $\mathrm{EA} / \mathrm{KEPK} / 2019$.

\section{RESULT}

Study results were gained from the distributed questionnaire and observation on healthcare workers who participated as respondents in this study. This study results were presented in frequency distribution and cross-tabulation as follows.

\section{Needlestick Injury and Its Factors}

Table 1 presents the respondents' distribution according to needlestick injury experience and factors that can cause needlestick injury which included educational level, knowledge, training, and unsafe action. Referring to table 1, as many as 29 respondents $(31.87 \%)$ have experienced needlestick injury for the past year. Meanwhile, more than half of the respondents $(68.13 \%)$ have never experienced needlestick injury for the past year.

As seen in table 1, it can be identified that most of the respondents $(46.2 \%)$ are respondents with diploma education, $71.4 \%$ of the respondents already have good knowledge about matters related to needlestick injury, and $54.9 \%$ of the respondents stated that the training given by the hospital was good enough or moderate. From table 1, it was also known that most of the respondents (52.7\%) performed unsafe actions that categorized as low. The categorization of unsafe actions was based on how much unsafe actions were carried out during work. The more unsafe actions are carried out then the higher the category obtained.

\section{The Analysis of Educational Level and Needlestick Injury}

Table 2 is an analysis in the form of crosstabulation as well as the significance of the
Table 1. The Frequency Distribution of Respondents Based on Needlestick Injury and Its Factors at the Hospital of Bojonegoro in 2019

\begin{tabular}{|c|c|c|}
\hline Variables & Frequency (n) & Percentage (\%) \\
\hline \multicolumn{3}{|c|}{ Needlestick Injury } \\
\hline Ever & 29 & 31.87 \\
\hline Never & 62 & 68.13 \\
\hline Total & 91 & 100 \\
\hline \multicolumn{3}{|c|}{ Educational Level } \\
\hline Diploma & 42 & 46.2 \\
\hline Bachelor & 36 & 39.5 \\
\hline Master & 13 & 14.3 \\
\hline Total & 91 & 100 \\
\hline \multicolumn{3}{|l|}{ Knowledge } \\
\hline Poor & 0 & 0 \\
\hline Moderate & 26 & 28.6 \\
\hline Good & 65 & 71.4 \\
\hline Total & 91 & 100 \\
\hline \multicolumn{3}{|l|}{ Training } \\
\hline Less & 0 & 0 \\
\hline Moderate & 50 & 54.9 \\
\hline Good & 41 & 45.1 \\
\hline Total & 91 & 100 \\
\hline \multicolumn{3}{|c|}{ Unsafe Actions } \\
\hline Low & 48 & 52.7 \\
\hline Moderate & 20 & 22.0 \\
\hline High & 23 & 25.3 \\
\hline Total & 91 & 100 \\
\hline
\end{tabular}

Table 2. The Analysis of Educational Level and Needlestick Injury at the Hospital of Bojonegoro in 2019

\begin{tabular}{cccccccc}
\hline \multirow{2}{*}{$\begin{array}{c}\text { Educational } \\
\text { Level }\end{array}$} & \multicolumn{3}{c}{ Needle Stick Injury } & \multicolumn{2}{c}{ Total } & \multirow{2}{*}{ Sig } \\
\cline { 2 - 6 } & \multicolumn{2}{c}{ Ever } & \multicolumn{2}{c}{ Never } & & & \\
\cline { 2 - 6 } & $\mathbf{n}$ & $\mathbf{\%}$ & $\mathbf{n}$ & $\mathbf{\%}$ & $\mathbf{N}$ & $\mathbf{\%}$ & \\
\hline Diploma & 16 & 38.1 & 26 & 61.9 & 42 & 100 & \\
Bachelor & 6 & 16.7 & 30 & 83.3 & 36 & 100 & 0.024 \\
Master & 7 & 53.8 & 6 & 46.2 & 13 & 100 & \\
\hline
\end{tabular}

relationship between education level and needlestick injury. Table 2 shows that 16 out of 29 respondents who encountered needlestick injuries were those who have Diploma education. Some of the respondents (38.1\%) with diploma education experienced needlestick injuries. As many as six respondents $(16.7 \%)$ with bachelor education experienced needlestick injuries. On the other hand, most of 
Table 3. The Analysis of Knowledge and Needlestick Injury at the Hospital of Bojonegoro in 2019

\begin{tabular}{cccccccc}
\hline \multirow{2}{*}{$\begin{array}{c}\text { Knowledge } \\
\text { Level }\end{array}$} & \multicolumn{3}{c}{ Needle Stick Injury } & \multicolumn{2}{c}{ Total } & \multirow{2}{*}{ Sig } \\
\cline { 2 - 6 } & \multicolumn{2}{c}{ Ever } & \multicolumn{2}{c}{ Never } & & & \\
\cline { 2 - 6 } & $\mathbf{n}$ & $\mathbf{\%}$ & $\mathbf{n}$ & $\mathbf{\%}$ & $\mathbf{N}$ & $\mathbf{\%}$ & \\
\hline Poor & 0 & 0 & 0 & 0 & 0 & 100 & \\
Moderate & 9 & 34.6 & 17 & 65.4 & 26 & 100 & 0.722 \\
Good & 20 & 30.8 & 45 & 69.2 & 65 & 100 & \\
\hline
\end{tabular}

Table 4. The Analysis of Training and Needlestick Injury at the Hospital of Bojonegoro in 2019

\begin{tabular}{cccccccc}
\hline \multirow{2}{*}{ Training } & \multicolumn{4}{c}{ Needle Stick Injury } & \multirow{2}{*}{ Total } & \multirow{2}{*}{ Sig } \\
\cline { 2 - 6 } & \multicolumn{2}{c}{ Ever } & \multicolumn{2}{c}{ Never } & & & \\
\cline { 2 - 7 } & $\mathbf{n}$ & $\mathbf{\%}$ & $\mathbf{n}$ & $\mathbf{\%}$ & $\mathbf{N}$ & $\mathbf{\%}$ & \\
\hline Moderate & 18 & 36.0 & 32 & 64.0 & 50 & 100 & \multirow{2}{*}{0.350} \\
Good & 11 & 26.8 & 30 & 73.2 & 41 & 100 & \\
\hline
\end{tabular}

the respondents $(53.8 \%)$ with master education experienced needlestick injuries.

The significance value of 0.024 was obtained from the chi-square test which points out that there is a relationship between educational level and needlestick injury. The contingency coefficient value was at 0.275 . This contingency coefficient value means that educational level and needlestick injury has a weak relationship.

\section{The Analysis of Knowledge and Needlestick Injury}

Table 3 shows the cross-tabulation and significance of the relationship between knowledge and needlestick injury. Based on table 3, among the 29 respondents who encountered needlestick injuries, 20 of them were respondents who have a good knowledge. According to table 3 , it can be seen that some respondents $(34.6 \%)$ with moderate knowledge experienced needlestick injuries. As many as 20 respondents $(30.8 \%)$ with good knowledge also experienced needlestick injuries.

After the chi-square test was done, the significance value showed at 0.722 . The statistical result indicates that there is no relationship between knowledge and needlestick injury.

\section{The Analysis of Training and Needlestick Injury}

Table 4 denotes the relationship between training and needlestick injury along with
Table 5. The Analysis of Unsafe Action and Needlestick Injury at the Hospital of Bojonegoro in 2019

\begin{tabular}{cccccccc}
\hline \multirow{2}{*}{$\begin{array}{c}\text { U s a f e } \\
\text { Actions }\end{array}$} & \multicolumn{4}{c}{ Needle Stick Injury } & \multirow{2}{*}{ Total } & \multirow{2}{*}{ Sig } \\
\cline { 2 - 6 } & \multicolumn{2}{c}{ Ever } & \multicolumn{3}{c}{ Never } & & \\
\hline Low & 9 & 18.8 & 39 & 81.2 & 48 & 100 & \\
Moderate & 6 & 30.0 & 14 & 70.0 & 20 & 100 & 0.002 \\
High & 14 & 60.9 & 9 & 39.1 & 23 & 100 & \\
\hline
\end{tabular}

its significance. Based on table 4, 18 out of 29 respondents who encountered needlestick injuries were those who stated that the training given by the hospital was good enough or moderate. Some of the respondents $(36 \%)$ who stated that the training given by the hospital was good enough or moderate, experienced needlestick injuries. In addition to that, as many as 11 respondents $(26.8 \%)$ who stated that the training provided by the hospital was good also experienced needlestick injuries.

Based on the results of the chi-square test, the significance value obtained was 0.350 . This significance indicates that there is no relationship between training and needlestick injury.

\section{The Analysis of Unsafe Actions and Needlestick Injury}

Table 5 presents a cross-tabulation of the unsafe actions and needlestick injury as well as the significance value. As can be seen in table 5 , among the 29 respondents who encountered needlestick injuries, 14 of them were respondents who performed unsafe actions that categorized as high. The majority of respondents $(60.9 \%)$ who performed unsafe actions that categorized as high, experienced needlestick injuries as well. Six respondents $(30 \%)$ who performed moderate unsafe actions also experienced needlestick injuries. Other than that, 9 respondents $(18.8 \%)$ who performed low unsafe actions experienced needlestick injuries.

The significance value of 0.002 was obtained from the chi-square test. This significance points out that there is a relationship between unsafe actions and needlestick injury. In addition, the value of the contingency coefficient was at 0.351 . This contingency coefficient value signifies that unsafe actions and needlestick injury have a moderate relationship. 


\section{DISCUSSION}

\section{Needlestick Injury}

Results of the study revealed that 29 healthcare workers have experienced needlestick injuries for the past year. Such number of accidents is higher than the number of accidents recorded in the infection prevention and control report in 2017 in which four cases of needlestick injuries were recorded. It can be seen that there were differences in the number of cases, which were 7 times higher than in 2017.

The considerable increase in the number of needlestick injury cases can be a result of not optimal occupational accident reporting. There are still many healthcare workers assume that needlestick injury is common. This assumption was also found in the results of a study conducted by Mawarni and Taiyep (2019) which stated that many healthcare workers who considered needlestick injury as a common occurrence.

The assumption hinders the healthcare workers to take the accident into a report to the hospital's authority. Those who have experienced needlestick injury prefer handling it themselves by cleaning the skin area with alcohol and without reporting it as an accident.

\section{Educational Level and Needlestick Injury}

According to Budiono, Jusuf and Pusparini (2016), formal education can facilitate an individual to prepare themselves for the professional world. Educational background can also contribute to one's ability to do their work activities.

The study results suggested that most respondents have diploma education. Based on the study results, it is also known that among the 29 workers who encountered needlestick injuries, most of them are diploma graduate. However, when the number of total respondents in each category is put into consideration, healthcare workers who have most cases of needlestick injury are master graduates. This study discovered that $53.8 \%$ of respondents with master education experienced needlestick injuries.

Statistical analysis results show that educational level has a relationship with needlestick injury. This study results conform to the study conducted by Ifadah and Susanti (2018) which indicates that the educational level has a significant relationship with needlestick injury. Additionally, Ozlu et al. (2017) also revealed that educational level is one of the factors related to needlestick injury.

Results of the study also in concordance with the study accomplished by Oluwatosin, Oladapo and Asuzu (2016) which stated that educational level and needlestick injury were significantly related. They also revealed that most of the healthcare workers who encountered needlestick injury were healthcare workers with master education. They believed that such condition happened due to the high frequency of needle used by master-educated healthcare workers during medical procedure.

In this study, from the number of workers with and without needlestick injury in each level of education, it can be seen that master graduates have encountered more needlestick injuries. The higher number in this particular level of education against the number of diploma graduates can be caused by health care workers who master' graduates may feel more confident with the knowledge and experience they have along with the high level of education that has been taken so they tend to be less careful and meticulous in carrying out their work activities which lead to occupational accident (Istih, Wiyono and Candrawati, 2017). This is in line with Aniwada and Onwasigwe (2016) who affirmed that a higher educational level does not always guarantee better practices in carrying out work.

\section{Knowledge and Needlestick Injury}

According to Bolisani and Bratianu (2018), knowledge is defined as a certain thing that is known by someone that comes from the perception of sense. Knowledge can be acquired from something learned and personal experience. In addition, a person's knowledge can also be obtained from shared information through one person to another.

The study results suggested that healthcare workers already have a moderate and good knowledge. Healthcare workers have been informed on matters related to needlestick injury. The knowledge includes information on using needles, the risk of needlestick injury, disposal of used needles, and wound treatment after being punctured by needles.

Referring to statistical analysis, it was found that knowledge is not related to needlestick injury. This is due to the fact that some workers have had moderate knowledge and some others have had good knowledge. In accordance with this study results, Puspitasari, Supriyanto and Ginanjar (2019) also 
revealed that knowledge and needlestick injury did not have any relationship.

Mekonnen et al., (2018) asserted that almost all of the healthcare workers who participated as respondents (94\%) already had good knowledge about needlestick injury and diseases that could be transmitted. However, in its implementation, most of the healthcare workers did not apply good practice related to the prevention of needlestick injury. Hence, many healthcare workers had needlestick injuries.

On the other hand, Mapanawang, Pandelaki and Panelewen (2017) had different results in their study. Based on their study, they revealed that there was a significant relationship between knowledge and needlestick injury. Workers with poor knowledge were exposed to 2.1 times more risks of needlestick injury than workers with good knowledge.

Geberemariyam, Donka and Wordofa (2018) affirmed that the factor of knowledge contributes to the improvement of healthcare workers' compliance in measures of preventing infection. Therefore, despite this study stating that knowledge was nit related to needlestick injury, knowledge remains as an important aspect in preventing infection that can arise from needlestick injury.

\section{Training and Needlestick Injury}

Training is a learning process carried out by a worker or a work unit that aims to improve the abilities and skills of the workers. Training is one important aspect in the management of occupational safety and health since training can be a supporting effort in preventing occupational accidents and occupational diseases (Tarwaka, 2017).

This study found that training has no significant relationship with needlestick injury. This could be due to the fact that healthcare workers have attended the training. The training which was attended by healthcare workers was a training program provided by the hospital. When a new employee first worked at this hospital, they were provided training by the hospital. As long as they work in this hospital, training will also be given to them.

Various training materials were provided by the hospital. The training materials provided included isolation awareness training, personal protective equipment (PPE) training, medical devices training, and medical waste training.

The needlestick injury prevention training was held by the infection prevention and control team who also acted as facilitators in the training. Before the training was carried out, the infection prevention and control team should give a pre-test to the training participants. This was followed by a post-test given after the training was complete. The infection prevention and control team gave a pre-test and posttest to measure the participants' knowledge before and after the training. The media used in needlestick injury prevention training were related equipment such as needles and PPE. In the training session, the facilitator provided theory and also practiced the mechanism in using needles in accordance with standard operating procedures. Thus, it was known that the hospital has facilitated workers through the implementation of comprehensive training.

Different results were obtained by Assen et al. (2020), who showed that there was a relationship between training and needlestick injury. Workers who did not take part in proper training had a higher risk of experiencing needlestick injury.

Although this study results pointed that training had no relationship with needlestick injury, the hospital should continue to carry out planned training programs for workers in the hospital. Training programs are still essential to be conducted as it can determine or contribute to the level of knowledge and skills of workers (Budiono, Jusuf and Pusparini, 2016). Additionally, Saha et al. (2017) argued that the training program on needlestick injury prevention is an effective strategy to decrease needlestick injury risks.

In addition, training for workers must be carried out since the majority of workers in this study stated that the training provided by the hospital was still in the moderate category. It indicates that improvement is still needed in the implementation of the training program.

Pursuant to Tarwaka (2017), the provision of training should be in accordance with the needs of certain training. To discover the need for certain training, identification of problems that occur in the workplace must be carried out comprehensively so that it can be determined whether training is needed to help overcoming these problems. This is intended to ensure that training can be effective and welltargeted.

Kebede and Gerensea (2018) in their study stated that effective training can improve workers' skills. Besides that, effective training can also increase workers' awareness to implement a strategy to prevent needlestick injury.

According to Budiono, Jusuf and Pusparini (2016), continuous training would increase 
workers' insight and awareness. Increasingly, insight improvement will eventually be followed by awareness improvement. Workers' enhanced awareness would enable them to get used to carry out their work properly and safely.

Training related to needlestick injury can be mainly given to workers who are at risk of needlestick injury (those who use needles in their work activities). This training can include procedures for using needles, disposing the used needles, and procedures after the accident. During training, the use of personal protective equipment (PPE) can also be emphasized so it can be consistently obeyed. Training on needlestick injury should be done routinely or continuously to refresh knowledge and increase the awareness of healthcare workers.

\section{Unsafe Action and Needlestick Injury}

Human actions are not only determined by knowledge. However, human actions are also determined by life experience and the influence of people around them. In the realm of occupational safety and health, there are terms of unsafe actions and safe actions. Unsafe actions constitute the biggest cause of occupational accidents at work. If unsafe actions escalate, incidents can also increase. Meanwhile, when safe actions increase then incidents can decrease (Tarwaka, 2018).

Referring to the study results, it was found that most of the healthcare workers with a high category of unsafe actions experienced needlestick injury. The second-largest number of respondents who experienced needlestick injury were respondents with moderate category of unsafe actions. After the statistical analysis was done, it was discovered that unsafe action has a relationship with needlestick injury. From the results of this study, it can be concluded that the greater the unsafe actions performed then the higher the potential of needlestick injury to happen.

Results of study conducted by Mawarni and Taiyep (2019) suggested that healthcare workers often experience needlestick injury caused by negligence in using personal protective equipment (PPE). Additionally, needlestick injury is also caused by the lack of compliance with standard operating procedures when conducting work activities using needles.

Based on this study, there were still many healthcare workers who did not use gloves when working with needles. In fact, gloves are personal protective equipment (PPE) that must be used when carrying out needle-involved work activities.

This hospital has provided gloves which are specifically designed to resist needle puncture. According to Martin et al. (2017), the use of latex or nitrile gloves can be considered as a physical barrier to protect self from needle puncture. Wearing gloves can prevent the needle from directly hit the skin and causing injury. Other than that, wearing gloves can also reduce the depth of needle puncture and minimize the transmission of microorganisms.

Alifariki and Kusnan (2019) stated that some workers were inconsistent in wearing gloves when conducting needle-involved activities. Another study revealed that healthcare workers who did not obey the rules to always use PPE had 3 times greater risk to be exposed to needlestick injury compared to those who always use PPE (Mekonnen et al., 2018).

Furthermore, as this study indicates, there were healthcare workers who still closed the needles after use, or often known as recapping. In addition, there were also used needles that were not immediately disposed in the trash bins for sharp objects (safety box). Such unsafe actions can potentially cause hands to be punctured by needles.

A study by Putri, Santoso and Rahayu (2018) supported this study's results. They revealed that needlestick injuries are caused by recapping with two hands and used needles that are not immediately thrown into the safety box. Another study also showed that there were still many healthcare workers who conducted unsafe actions such as closing the used needles and not disposed the needle into proper place (Abubakar et al., 2019)

According to Assen et al. (2020), healthcare workers who do recapping are 2.63 times more likely to have needlestick injury than those who do not. Therefore, recapping is an action that is not recommended to be conducted. However, if this action needs to be conducted, healthcare workers should use recapping technique with one hand. Recapping technique using one hand is considered safer than using two hands (Ali et al., 2020).

Unsafe actions indicate that in its implementation, healthcare workers have not fully implemented the provisions contained in Minister of Health Regulation Number 27 of 2017 which confirms that closing a needle that has been used (recapping) is not a recommended action. Used needles should be disposed immediately to a puncture-proof container such as safety box. This 
measure is implemented to prevent hands from being punctured by needles.

Unsafe actions that are still conducted by healthcare workers must be controlled and should not be ignored. Emphasize should be given to the control of unsafe actions that often occur. Workers must be constantly reminded and directed to carry out the work activities safely.

In this case, there still no hospital policy that explicitly regulates the responsibility of each employee to reprimand and report unsafe actions that occur. Such policy is one of the efforts that the hospital can take to help prevent and reduce unsafe action case. The reporting is not intended to give a punishment to workers for their unsafe actions. However, reporting is intended to identify any unsafe actions conducted by the workers. Reporting of unsafe actions at work can also be submitted as considerations for determining further control strategy. This way, occupational accidents on healthcare workers such as needlestick injury can be minimized.

\section{CONCLUSION}

The study discovers that some workers experienced needlestick injury for the past year. The results of the statistical analysis show that educational level and unsafe actions have a relationship with needlestick injury among healthcare workers at one of the hospitals in Bojonegoro. Meanwhile, there is no relationship between knowledge and training with needlestick injury on healthcare workers at one of the hospitals in Bojonegoro .

\section{ACKNOWLEDGEMENTS}

First, we would like to send gratitude to Allah SWT for all grace and blessing. Thank you to all of the lecturers in Public Health Faculty, particularly The Department of Occupational Safety and Health, for the insights and lessons. Gratitude is also sent to all parties who have supported this study in various ways, from wishing the best to contribute to the completion of this article.

\section{REFERENCES}

Abubakar, S. et al. (2019) 'Knowledge and Practice of Injection Safety Among Healthcare Workers In A Nigerian Secondary Healthcare Facility',
International Journal of Infection Control, 15(1), pp. 1-8.

Al-Abhar, N. et al. (2020) 'Occupational Exposure to Needle Stick Injuries and Hepatitis B Vaccination Coverage Among Clinical Laboratory Staff in Sana'a, Yemen: Cross-Sectional Study', JMIR Public Health and Surveillance, 6(1), pp. 1-6.

Ali, S. et al. (2020) 'Knowledge, Awareness, and Practices Regarding Needlestick Injury among Health-Care Workers in A Tertiary Care Hospital of India: Annual Incidence Versus Reporting Rate', International Journal of Health \& Allied Sciences, 9(1), pp. 45-50.

Alifariki, L. O. and Kusnan, A. (2019) 'Hubungan Praktek Menyuntik Aman dengan Kejadian Cedera Tertusuk Jarum', Jurnal Perawat Indonesia, 3(3), pp. 229-236.

Aniwada, E. and Onwasigwe, C. (2016) 'Safety Precaution; Knowledge, Attitude, Practice and Sociodemographic Determinants among Health Care Workers at Primary Health Care Level in Enugu State, Nigeria', International Journal of Tropical Disease \& Health, 16(4), pp. 1-13.

Assen, S. et al. (2020) 'Magnitude and Associated Factors of Needle Stick and Sharps Injuries Among Health Care Workers in Dessie City Hospitals, North East Ethiopia', BMC Nursing, 9(31), pp. 1-8.

Bolisani, E. and Bratianu, C. (2018) Knowledge Management and Organizational Learning. Volume 4 Series editors. Switzerland: Springer International Publishing.

Bouya, S. et al. (2020) 'Global Prevalence and Device Related Causes of Needle Stick Injuries among Health Care Workers: A Systematic Review and Meta-Analysis', Annals of Global Health, 86(1), pp. 1-8.

Braeseke, G. et al. (2011) Occupational Health and Safety Risks In The Healthcare Sector. Luxembourg: European Union.

Budiono, S., Jusuf, R. M. S. and Pusparini, A. (2016) Bunga Rampai Hiperkes dan KK. Semarang: Badan Penerbit Universitas Diponegoro.

Çiçek-Şentürk, G. et al. (2019) 'Retrospective Investigation of 9 Years of Data on Needlestick and Sharps Injuries: Effect of A Hospital Infection Control Committee', American Journal of Infection Control, 47(2), pp. 186-190.

Garus-Pakowska, A. and Górajski, M. (2019) 'Epidemiology of Needlestick and Sharp Injuries Among Health Care Workers Based on Records 
From 252 Hospitals for The Period 2010-2014, Poland', BMC Public Health, 19(1), pp. 1-8.

Geberemariyam, B. S., Donka, G. M. and Wordofa, B. (2018) 'Assessment of knowledge and practices of healthcare workers towards infection prevention and associated factors in healthcare facilities of West Arsi District, Southeast Ethiopia: A facilitybased cross-sectional study', Archives of Public Health, 76(1), pp. 1-11.

Goel, V. et al. (2017) 'Occurrence of Needlestick and Injuries among Health-care Workers of a Tertiary Care Teaching Hospital in North India', Journal of Laboratory Physicians, 9(1), pp. 20-25.

Ifadah, E. and Susanti, F. (2018) 'Analisis Faktor yang Berhubungan dengan Kejadian Needle Stick Injury di Ruang Instalasi Gawat Darurat dan Ruang Intensive Care RSUD Pasar Rebo Jakarta', Jurnal Keperawatan Respati Yogyakarta, 5(1), pp. 315-321.

International Labour Organization (2015) Investigation of Occupational Accidents and Diseases: A Practical Guide for Labour Inspectors. Geneva: ILO Publications.

Istih, S. M. P., Wiyono, J. and Candrawati, E. (2017) 'Hubungan Unsafe Action Dengan Kecelakaan Kerja Pada Perawat Di Rumah Sakit Panti Waluya Malang', Nursing News: Junral Ilmiah Keperawatan, 2(2), pp. 337-348.

Kebede, A. and Gerensea, H. (2018) 'Prevalence of Needle Stick Injury and Its Associated Factors among Nurses Working In Public Hospitals of Dessie Town, Northeast Ethiopia, 2016', BMC Research Notes, 11(1), pp. 1-6

Laranova, A., Afriandi, I. and Pratiwi, Y. S. (2018) 'Persepsi Tenaga Kesehatan terhadap Penggunaan Alat Pelindung Diri dan Kejadian Kecelakaan Akibat Kerja di Salah Satu Rumah Sakit di Kota Bandung', Jurnal Sistem Kesehatan, 3(4), pp. 189-197.

Mapanawang, S., Pandelaki, K. and Panelewen, J. (2017) 'Hubungan antara Pengetahuan, Kompetensi, Lama Kerja, Beban Kerja dengan Kejadian Tertusuk Jarum Suntik pada Perawat di RSUD Liun Kendage Tahuna', Jurnal EMBA, 5(3), pp. 4336-4345.

Martin, A. et al. (2017) 'Microneedle Manufacture: Assessing Hazards and Control Measures', Safety, 3(4), pp. 1-13.

Mawarni, T. and Taiyep, A. A. (2019) 'Insiden Kecelakaan Kerja Pada Petugas di Rumah Sakit TK. III Dr. R. Soeharsono Banjarmasin',
Proceeding of Sari Mulia Universty Nursing National Seminars, 1(1), pp. 182-194.

Mekonnen, R. et al. (2018) 'Magnitude and Impact of Occupational Related Needle Stick and Sharp Injuries and Associated Factors among Health Care Workers in Dire Dawa, Eastern Ethiopia', Medical Safety \& Global Health, 7(1), pp. 1-7.

Minister of Health Regulation (2016) Number 66 of 2016. Concerning Occupational Safety and Health in Hospitals. Jakarta: Ministry of Health Republic of Indonesia.

Minister of Health Regulation (2017) Number 27 of 2017. Concerning Guidelines for Prevention and Control of Infection in Healthcare Facilities. Jakarta: Ministry of Health Republic of Indonesia.

Minister of Health Regulation (2018) Number 52 of 2018. Concerning Occupational Safety and Health in Healthcare Facilities. Jakarta: Ministry of Health Republic of Indonesia.

Oluwatosin, O. A., Oladapo, M. M. and Asuzu, M. C. (2016) 'Needlestick Injuries Among Health Care Workers In Ondo State, Nigeria', International Journal of Medicine and Public Health, 6(1), pp. 31-34.

OSHA (2013) Facts About Hospital Worker Safety. Washington: Occupational Safety and Health Administration.

Ozlu, Z. K. et al. (2017) 'The Safe Use of Sharps and Needlestick among Nurses Working in Surgical Clinics, Turkey', Eurasian Journal of Emergency Medicine, 15(4), pp. 187-192.

Puspitasari, S., Supriyanto and Ginanjar, R. (2019) 'Faktor-Faktor yang Berhubungan dengan Kecelakaan Tertusuk Jarum Suntik atau Benda Tajam Lainnya pada Perawat di RSUD Leuwiliang Kabupaten Bogor Tahun 2018', PROMOTOR Jurnal Mahasiswa Kesehatan Masyarakat, 2(2), pp. 163-171.

Putri, S., Santoso, S. and Rahayu, E. P. (2018) 'Pelaksanaan Keselamatan dan Kesehatan Kerja Terhadap Kejadian Kecelakaan Kerja Perawat Rumah Sakit', Jurnal Endurance, 3(2), pp. 271-277.

Ramdan, I. M. and Rahman, A. (2018) 'Analisis Risiko Kesehatan dan Keselamatan Kerja (K3) pada Perawat', Jurnal Keperawatan Padjadjaran, 5(3), pp. 229-241.

Ramli, S. (2010) Sistem Manajemen Keselamatan dan Kesehatan Kerja OHSAS 18001. Jakarta: Dian Rakyat. 
Saha, R. et al. (2017) 'Needle Stick Injury among Health Care Workers and Its Aftermath in a Tertiary Care Hospital in East Delhi, India', Journal of Communicable Diseases, 49(1), pp. 14-20.

Sastry, A. S., Rajshekhar, D. and Bhat, P. (2017) 'Needlestick, Sharp, and Splash Injuries In a Tertiary Care Government Hospital of South India', Journal of Current Research in Scientific Medicine, 3(2), pp. 94-101.

Soleman, S. R. and Nugroho, T. (2017) 'Risk Factors Sharp Injury Among Healthcare Workers in Sleman State Hospital Yogyakarta Province Indonesia', Jurnal Kedokteran dan Kesehatan Indonesia, 8(1), pp. 58-67.

Sriram, S. (2019) 'Study of Needle Stick Injuries among Healthcare Providers: Evidence from a Teaching Hospital in India', Journal of Family Medicine and Primary Care, 8(2), pp. 599-603.
Tarwaka (2017) Keselamatan dan Kesehatan Kerja: Manajemen dan Implementasi K3 di Tempat Kerja. Surakarta: Harapan Press.

Tarwaka (2018) Keselamatan, Kesehatan Kerja dan Ergonomi (K3E) dalam Perspektif Bisnis. Surakarta: Harapan Press.

World Health Organization and International Labour Organization (2018) Occupational Safety and Health in Public Health Emergencies: A Manual for Protecting Health Workers and Responders. Geneva: ILO Publications.

Yazie, T. D., Chufa, K. A. and Tebeje, M. G. (2019) 'Prevalence of Needlestick Injury among Healthcare Workers In Ethiopia: A Systematic Review and Meta-Analysis', Environmental Health and Preventive Medicine, 24(1), pp. $1-10$. 